\title{
P086: Prospective surveillance from the laboratory of multidrug-resistant bacteria (MDRB) bacteremia
}

\author{
NM Dia ${ }^{1 *}$, A Ndir $^{2}$, R Ka $^{3}$, KL Onanga ${ }^{3}$, ML Dia $^{3}$, B Ndoye $^{2}$, Al Sow $^{3}$, M Seydi $^{1}$ \\ From 2nd International Conference on Prevention and Infection Control (ICPIC 2013) \\ Geneva, Switzerland. 25-28 June 2013
}

\section{Introduction}

The control of the diffusion of the MDRB in health establishments is a priority.

\section{Objectives}

Our work studied the incidence of bacteremia due to MDRB in a hospital environment.

\section{Methods}

Microbiological surveillance was led in three departments of a teaching hospital during a period of six months going from April till October 2012 and concerning only blood cultures with diagnostic aim.

\section{Results}

During the study period, 123 patients were followed and 30 episodes of bacteremia were described that is $21 \%$ of all the blood cultures taken. The average age of the patients was 49 years \pm 18.31 and the sex-ratio 0.66 . The majority of the patients $(78.6 \%)$ were sent by a health care structure, $14.3 \%$ came from the place of residence and $7.1 \%$ were the object of internal transfer. Thirty six percent of the patients were admitted for a neurological disorder with an average duration of stay of 19.66 days \pm 14.62 . Positive blood cultures were attributed to nosocomial infections in 22 cases $(75.9 \%)$ with an average delay of acquisition of 14.55 days. On the bacteriological plan, the responsible microorganisms were established: Enterobacteriaceae 17 (56.7\%) among which 11 (64.7\%) producing extendedspectrum beta-lactamases (ESBL), non fermenting Gramnegative bacteria 4 (13.3\%), Gram-positive bacteria 9 (30\%) among which 4 methicillin-resistant Staphylococcus aureus (MRSA). Klebsiella pneumoniae was the dominant microorganism 8 (26.7\%). The presence of a catheter was identified in 7 cases of bacteremia associated with an

${ }^{1}$ Infectious Diseases Department, Fann Teaching Hospital, Dakar, Senegal Full list of author information is available at the end of the article
Enterobacteriaceaeproducing ESBL. The rate of attack MDRB was 1.54 for 100 admissions and the incidence rate was 1.66 for 1000 patient-days. After bacteremia, the death rate was $61.5 \%$.

\section{Conclusion}

The incidence of the MDRB during bacteremia is high in our structure. A program of prevention of the diffusion of the MDRB should be set up, accompanied with a training of nursing staff.

\section{Disclosure of interest}

None declared.

\section{Author details}

${ }^{1}$ Infectious Diseases Department, Fann Teaching Hospital, Dakar, Senegal. ${ }^{2}$ Pronalin, Ministry of Health, Dakar, Senegal. ${ }^{3}$ Laboratory of Bacteriology, Fann Teaching Hospital, Dakar, Senegal.

Published: 20 June 2013

\section{doi:10.1186/2047-2994-2-S1-P86}

Cite this article as: Dia et al:: P086: Prospective surveillance from the laboratory of multidrug-resistant bacteria (MDRB) bacteremia. Antimicrobial Resistance and Infection Control 2013 2(Suppl 1):P86.

Submit your next manuscript to BioMed Central and take full advantage of:

- Convenient online submission

- Thorough peer review

- No space constraints or color figure charges

- Immediate publication on acceptance

- Inclusion in PubMed, CAS, Scopus and Google Scholar

- Research which is freely available for redistribution

\section{Biomed Central}

(c) 2013 Dia et al; licensee BioMed Central Ltd. This is an Open Access article distributed under the terms of the Creative Commons Attribution License (http://creativecommons.org/licenses/by/2.0), which permits unrestricted use, distribution, and reproduction in any medium, provided the original work is properly cited. 